\title{
35 Year achievements of Brazilian Oral Research
}

\section{Sigmar de Mello RODE(a) (ii) Saul Martins PAIVA(b)}

(a) Universidade Estadual Paulista - Unesp, Institute of Science and Technology, Department of Dental Materials and Prosthesis, São José dos Campos, SP, Brazil.

(b) Universidade Federal de Minas Gerais UFMG, School of Dentistry, Department of Pediatric Dentistry, Belo Horizonte, MG, Brazil.
Declaration of Interests: The authors certify that they have no commercial or associative interest that represents a conflict of interest in connection with the manuscript.
Abstract: This editorial addresses the history of Brazilian Oral Research (BOR), official journal of the Brazilian Division of the International Association of Dental Research (SBPqO). BOR is increasingly consolidating itself as the most important journal in Brazilian dental research. However, much still needs to be done. The hard and continuous work to improve the journal will guarantee its permanent growth and result in new achievements for the benefit of the entire dental scientific community.

Keywords: Editorial; Dental Research; Periodicals as Topic.

\section{Introduction}

The history of Brazilian Oral Research (BOR) began in 1996, under the presidency of Professor João Humberto Antoniazzi (FOUSP). At that time, the General Meeting of the Brazilian Society for Dental Research (SBPqO) felt the need to create its own journal and set up a committee to design it. The committee was composed of Professors Esther Goldenberg Birman (FOUSP), Jaime Aparecido Cury (FOP/Unicamp), and João Adolfo Caldas Navarro (FOB/USP). In 1997, under the presidency of Professor Esther Goldenberg Birman (FOUSP), the committee suggested that the previously existing Dental Journal of the University of São Paulo (Figure 1) should become the official journal of SBPqO, rather than creating a new journal. The suggestion was unanimously approved at the General Meeting.

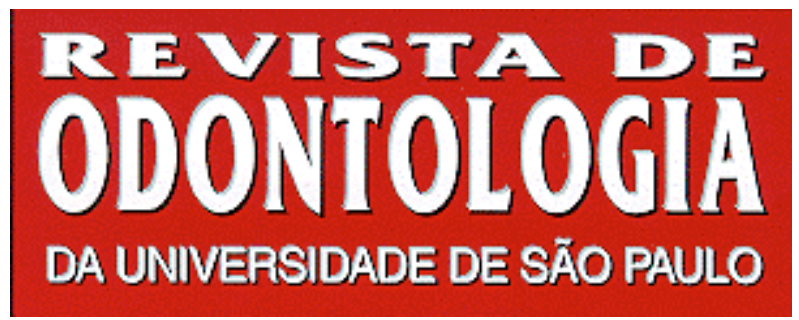

Figure 1. Logo of the Dental Journal of the University of São Paulo (created by 'Imprensa Científica'). 
Still in 1997, Birman ${ }^{1}$ wrote an editorial to announce that the Dental Journal of the University of São Paulo had been chosen as the official journal of the Brazilian Society for Dental Research (Brazilian Division of IADR).

The former 'Revista de Odontologia da Universidade de São Paulo' (Dental Journal of the University of São Paulo) had been set up in 1987, by joining journals from the three-existing dental schools of the University of São Paulo. It was also one of the periodicals invited to start SciELO database (https://scielo.org/), which it joined in 1998. Also, in 1998 it became part of the important Medline database. ${ }^{2}$

In 2000, under the presidency of Professor Sigmar de Mello Rode, the SBPqO General Meeting deliberated and decided to change the name of the journal to 'Pesquisa Odontologica Brasileira' (РОB - Brazilian Oral Research) (Figure 2). Professor Esther Goldenberg Birman (FOUSP) continued as Editor-in-Chief. In 2000, Birman ${ }^{3}$ wrote "after 13 years, the Dental Journal of the University of São Paulo is changing its name, but the objectives proposed at its inception, in 1987, remain the same. The search for improvement, wider dissemination, and greater coverage in Brazil and abroad has encouraged us to change its name, even though its original name was associated with a prominent institution like the University of São Paulo".

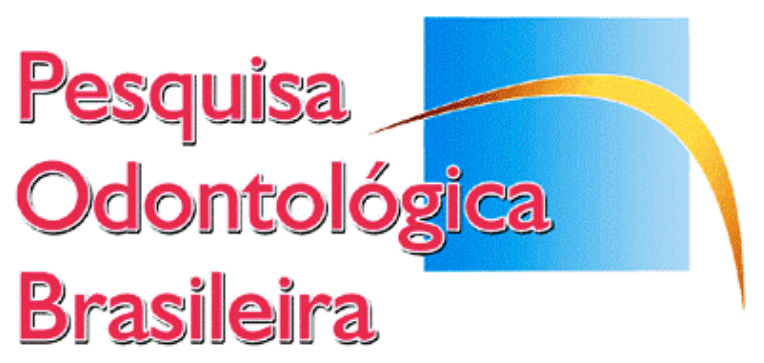

Figure 2. Logo of the Brazilian Dental Research journal (created by 'Imprensa Científica').

In 2000, Rode $^{2}$ mentioned that POB had been invited to join Elsevier's Scopus base. In 2003, under the presidency of Professor Fernando Ricardo Xavier da
Silveira, rose the need to internationalize POB. Then, a committee was established with former President of SBPqO Professors Esther Goldenberg Birman (FOUSP - Editor-in-Chief), José Luiz Lage-Marques (FOUSP), and Sigmar de Mello Rode (FOSJC/Unesp) to propose a new journal format. They eventually came up with Brazilian Oral Research, a journal fully edited in English. The proposal was approved at SBPqO's 2003 General Meeting.

In 2003, in the last POB issue, Associate Editor Lage-Marques ${ }^{4}$ wrote an editorial saying that "SBPqO is honored to publish this supplement that encourages the formal and conceptual development of scientific research, education, and writing, always observing the ethical principles involved in the execution and authorship, as well as in the presentation of experimental findings".

Thus, Brazilian Oral Research (BOR) (Figure 3) was launched in 2004, as the official publication of the Brazilian Division of IADR (SBPqO). In 2006, under presidency of Professor João Humberto Antoniazzi, due to health problems, Professor Esther Goldenberg Birman left BOR editorial office, a position she held with great dedication and competence. Professor Sigmar de Mello Rode (FOSJC/Unesp), who was already an Associate Editor, was appointed Editor-in-Chief.

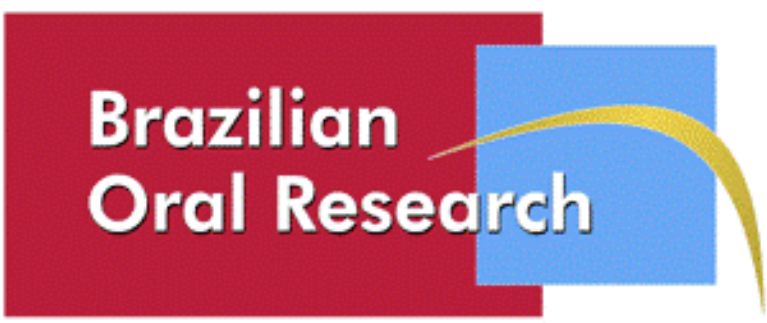

Figure 3. Brazilian Oral Research logo (created by 'Imprensa Científica').

In 2008, Rode ${ }^{5}$ and Lotufo ${ }^{6}$ announced changes in BOR publication rules aimed at adapting it to international standards and the registration of clinical trials. In another innovative initiative, they issued a call for voluntary members who wished to become manuscript reviewers. 
Table 1. Evolution of citation metrics of Brazilian Oral Research (BOR): Impact Factor (IF) of Web of Science (WoS), SciELO, and CiteScore of Scopus.

\begin{tabular}{|c|c|c|c|c|}
\hline \multirow{2}{*}{ Year } & \multirow{2}{*}{ Impact Factor WoS 3 years } & \multirow{2}{*}{ Impact Factor WoS 3 years } & CiteScore & \multirow{2}{*}{ Impact Factor SciELO 2 years } \\
\hline & & & Scopus & \\
\hline 2019 & 1.633 & 1.529 & 2.6 & 0.2667 \\
\hline 2018 & 1.773 & 1.766 & 2.2 & 0.25 \\
\hline 2017 & 1.223 & 1.492 & 1.8 & 0.2598 \\
\hline 2016 & 1.331 & 1.361 & 1.8 & 0.2412 \\
\hline 2015 & 0.859 & - & 2.2 & 0.3571 \\
\hline 2014 & 0.937 & - & 1.9 & 0.3222 \\
\hline 2013 & 0.774 & - & 1.7 & 0.3526 \\
\hline 2012 & - & - & 1.6 & 0.4601 \\
\hline 2011 & - & - & 1.4 & 0.3558 \\
\hline
\end{tabular}

In 2009, under the presidency of Professor Célio Percinoto, BOR General Regulation was presented by the Editor-in-Chief and approved at the General Meeting. The regulation determined how the journal should function, proposed a five-year term for the position of Editor-in-Chief, three-year terms for Associate Editors, and named Professor Esther Goldenberg Birman as life-long honorary Editor.

The first Editor-in-Chief approved by the General Meeting, after the new regulation, was Professor Sigmar de Mello Rode (FOSJC/Unesp), for the 2009/2014 term.

In 2010, in a bold move, BOR became a bimonthly publication (as of 2011) and made new changes to its editorial policy. ${ }^{7}$ It then began to adopt ahead of print as means to expedite the publication of approved manuscripts.

In 2011, Nicolau, ${ }^{8}$ founding partner and first President of $\mathrm{SBPqO}$, wrote a memorable editorial telling the story of SBPqO since it was first proposed, on June 15, 1982, until its actual foundation on May 5, 1983.

In 2012, a big dream came true: after several attempts, BOR was finally accepted at Journal of Citation Reports of the Web of Science. ${ }^{9}$ Also in 2012, Rode ${ }^{10}$ informed that BOR had adopted Scholar One system for manuscript submission. It was one of the first (the eighth) in SciELO collection to adopt the system.

In 2014, BOR discontinued its printed edition and adopted the continuous flow format. Its first impact factor was 0.774 (Table 1).
Table 2. Publications in BOR from 2004 to 2020.

\begin{tabular}{|c|c|c|c|c|}
\hline Year & Manuscripts & Supplement & Fascicles & Editorial \\
\hline 2004 & 58 & - & 4 & 4 \\
\hline 2005 & 51 & - & 4 & 4 \\
\hline 2006 & 58 & - & 4 & 2 \\
\hline 2007 & 58 & 1 & 5 & 4 \\
\hline 2008 & 59 & 1 & 5 & 5 \\
\hline 2009 & 70 & 1 & 5 & 5 \\
\hline 2010 & 72 & 1 & 5 & 5 \\
\hline 2011 & 83 & - & 6 & 6 \\
\hline 2012 & 85 & 1 & 7 & 8 \\
\hline 2013 & 73 & - & 6 & 7 \\
\hline 2014 & 83 & 1 & 2 & 3 \\
\hline 2015 & 120 & - & 1 & - \\
\hline 2016 & 140 & - & 1 & - \\
\hline 2017 & 113 & 1 & 2 & 1 \\
\hline 2018 & 129 & 1 & 2 & - \\
\hline 2019 & 118 & 1 & 2 & 1 \\
\hline 2020 & 124 & 2 & 3 & 2 \\
\hline
\end{tabular}

At the 2014 General Meeting, under the presidency of Professor Luiz Alberto Plácido Penna, Professor Giuseppe Alexandre Romito (FOUSP) was appointed and approved as Editor-in-Chief for the 2015/2019 period. 'Imprensa Científica', the company that had edited the journal until then, was replaced by 'Caboverde'.

In 2016, BOR scored impact factor index above 1 for the first time: 1.331. In 2017, Romito ${ }^{11}$ informed that BOR reached 'Qualis A2' in Capes Dentistry 
area ranking and began to publish special thematic issues with guest editors.

At the 2019 General Meeting, under the presidency of Professor Isabela Almeida Pordeus, Professor Saul Martins Paiva (UFMG) was appointed and approved as Editor-in-Chief for the 2019/2024 period.

In a review of SciELO, in September 2020, Brazilian Oral Research reached the significant figures of 2,825 received citations and 40,323 granted citations. On Google Scholar (2020), it presented the h5 index of 31 and a median h5 of 41 .
BOR is increasingly consolidating itself as the most important journal in Brazil's Dentistry area, with substantial and robust figures. However, much still needs to be done. Challenges like the adoption of Open Science principles and reaching an impact factor index over 2 will only be overcome if the whole scientific community, and particularly SBPqO members continue to engage in this pursuit.

Make sure to cite us in your studies, read our manuscripts and do not forget to talk about BOR, our most valuable asset.

\section{References}

1. Birman EG. Editorial. Rev Odontol Univ São Paulo. 1997;11(s1). https://doi.org/10.1590/S0103-06631997000500001

2. Rode SM. The advancing internationalization of our research. Braz Oral Res. 2008 Oct-Dec;22(4):291. https://doi.org/10.1590/S1806-83242008000400001

3. Birman EG. Editorial. Pesq Odontol Bras. 2000 Jan-Mar;14(1):00. https://doi.org/10.1590/S1517-74912000000100001

4. Lage-Marques JL. Uma nova ferramenta de consulta para o pesquisador na POB: como ensinar, pesquisar, redigir e publicar. Pesq Odontol Bras. 2003 May;17(1):00. https://doi.org/10.1590/S1517-74912003000500001

5. Rode SM. The BOR is changing its submission instruction. Braz Oral Res. 2008 Jan-Mar;22(1):3. https://doi.org/10.1590/S1806-83242008000100001

6. Lotufo MA. Clinical trial registration: now required. Braz Oral Res. 2008 Apr-June;22(2):99. https://doi.org/10.1590/S1806-83242008000200001

7. Publishing Comission. Revised publishing policy. Braz Oral Res. 2011 Jan-Feb;25(1):4. https://doi.org/10.1590/S1806-83242011000100001

8. Nicolau J. Memoirs of the Sociedade Brasileira de Pesquisa Odontológica (Brazilian Society of Dental Research). Braz Oral Res. 2011 Nov-Dec;25(6):476-7. https://doi.org/10.1590/S1806-83242011000600001

9. Rode SM. Editorial consolidation, a reality. Braz Oral Res. 2012 Jan-Feb;26(1):4. https://doi.org/10.1590/S1806-83242012000100001

10. Rode SM. ScholarOne and Web of Science: Preeminent submission, peer review and indexation. Braz Oral Res. 2012 SeptOct;26(5):387. https://doi.org/10.1590/S1806-83242012000500001

11. Romito GA. Editorial. Braz Oral Res. 2017 Aug;31 (l):e77. https://doi.org/10.1590/1807-3107bor-2017.vol31.0077 